\title{
IAPLL President
}

Peter D. MacIntyre

Cape Breton University, Canada

\section{Editors-in-Chief}

Phil Hiver

Florida State University, United States

Shaofeng Li

Ali H. Al-Hoorie

Florida State University, United States

Royal Commission for Jubail and Yanbu, Saudi Arabia

\section{Founding Editors}

Jo Mynard

Imelda Brady

Sarah Mercer

Kanda University of International Studies, Chiba, Japan

University of Granada, Granada, Spain

University of Graz, Graz, Austria

\section{Editorial Board}

Sonja Babic
Imelda K. Brady
Jean-Marc Dewaele
Tammy Gregersen
Honggang Liu
Peter D. MacIntyre
Sarah Mercer
Jo Mynard
Merissa Ocampo
Stephen Ryan
Muhammad Shahbaz
Kyle R. Talbot
Yasser Teimouri
Amy Thompson

University of Graz, Graz, Austria

University of Granada, Granada, Spain

Birkbeck, University of London, London, UK

American University of Sharjah, United Arab Emirates

Northeast Normal University, Changchun, China

Cape Breton University, Sydney, Nova Scotia, Canada

University of Graz, Graz, Austria

Kanda University of International Studies, Chiba, Japan

Fukushima Gakuin College, Fukushima, Japan

Waseda University, Tokyo, Japan

Government College Women University, Sialkot, Pakistan

University of Graz, Graz, Austria

Bogazici University, Turkey

West Virginia University, Morgantown, USA 


\title{
Special Issue: The Psychology of Teaching and Learning Content \& Language
}

\author{
Guest Editors: Kyle R. Talbot, Marie-Theres Gruber, \& Rieko Nishida
}

\section{Editorial}

Kyle R. Talbot, Marie-Theres Gruber, \& Rieko Nishida

Introduction to the Special Issue

\section{Research Articles}

Kristiina Skinnari

CLIL Challenges: Secondary School CLIL Teachers' Voices and Experienced Agency in Three European Contexts.

Yolanda Ruiz de Zarobe \& Simone Smala

Metacognitive Awareness in Language Learning Strategies and Strategy Instruction in CLIL Settings

Julia Goetze

Investigating Foreign Language Teacher Anxiety Using SFL's ATTITUDE and TRANSITIVITY Systems....

Nashwa Nashaat-Sobhy \& Davinia Sánchez-Garcia

Lecturers' Appraisals of the Use of English as a Lingua Franca in Higher Education Settings....

Gianna Hessel, Kyle R. Talbot, Marie-Theres Gruber, \& Sarah Mercer

The Well-being and Job Satisfaction of Secondary CLIL and Tertiary EMI Teachers.....

Josephine Moate \& Maria Ruohotie-Lyhty

Becoming a Bilingual Class Teacher: Experiencing and Making Sense through Two Languages in Teacher Education.

\section{Work-in-Progress}

Silvia Bauer-Marschallinger

Involving Students in Educational Design: How Student Voices Contribute to Shaping Transdisciplinary CLIL History Materials.

\section{Book Review}

Dorota Záborská

Book Review: Contemporary Language Motivation Theory - 60 Years Since Gardner and Lambert (1959) by Ali H. Al-Hoorie and Peter D. Maclntyre. 


\title{
Introduction to the Special Issue: The Psychology of Teaching and Learning Content and Language
}

\author{
Kyle R. Talbot ${ }^{1}$, Marie-Theres Gruber ${ }^{2}$ \& Rieko Nishida ${ }^{3}$ \\ ${ }^{1}$ University of Graz, ${ }^{2} \mathrm{KPH}$ Graz, ${ }^{3}$ Osaka University
}

We are pleased to present the first special issue for the Journal for the Psychology of Language Learning (JPLL). The existence of this journal suggests an increased recognition of the importance of psychological factors in language teaching and learning. Indeed, the once emerging field of the psychology of language learning and teaching (PLLT) seems to have cemented itself as a permanent subdiscipline within applied linguistics. With this special issue we want to take the opportunity to draw attention to the psychological experiences of stakeholders in integrated content and language (ICL) settings. These settings present unique challenges and opportunities for teachers and learners and remain relatively underexplored (cf. De Smet et al., 2018; Doiz \& Lasagabaster, 2018; Gierlinger, 2007; Gruber et al., 2020; Moate, 2011; Pappa et al., 2017). As such, our principle aim with this special issue is to draw increased attention to this domain of research in the hopes of uncovering ways to better support teachers and learners in these specific settings.
In the broadest possible terms, in ICL programs, "content" (e.g., history, biology, etc.) is taught to students in a language that does not correspond to the home language of the majority of the students in the classroom (Macaro et al., 2018). Examples of this include immersion, contentbased instruction (CBI), Content and Language Integrated Learning (CLIL), and foreign and English medium instruction (FMI/EMI) among others. Such programs can be found across the world and occur at all phases of education (Cenoz, Genesee \& Gorter, 2014; Coyle, 2013; Dearden, 2015). Furthermore, researchers suggest that ICL programs are likely to continue spreading into the future (Dearden 2015; Macaro et al., 2018). Macaro et al. (2018), for example, suggest that "it is hard to see anything but further expansion of EMI in HE” (p. 68). Though they refer to EMI at the tertiary level specifically, a similar argument can be made for other ICL programs. 
One useful lens through which to view the implementation of ICL programs is through the lens of educational innovation or reform (Banegas, 2012; Hüttner et al., 2013; Klaassen \& de Graaf, 2000; Talbot, Gruber, \& Nishida, 2021). Day (2007), for example, points out that although educational reforms vary widely, they hold some similarities. For example, he suggests that they may “challenge teachers' existing practices, resulting in at least temporary destabilization” (p. 598). Similarly, Klaassen and de Graaf (2001) suggest that innovations "are likely to arouse questions, uncertainties, and possibly resistance to new situations or changing demands" (p. 3). Klaassen and de Graaf (2001) refer primarily to EMI lecturers, yet such educational changes naturally impact learners too (Noguera, 2006).

Arguably, it is in the midst of such changes where a focus on the psychologies of teachers and learners is especially important. Such programs are distinct from traditional content- or language-focused classes and it stands to reason that the experiences of teachers and learners in such ICL contexts may be dissimilar. For instance, such programs may require teachers and learners to take on new roles and, in some cases, expand the scope of their responsibilities (e.g., Bovellan, 2014; Griva et al., 2014; Moate, 2011). Teachers and learners alike may also experience language anxiety or insecurity as they try to explain or learn complex content in a language that they themselves might still be learning (Aiello et al., 2017; Doiz et al., 2014; Pappa, 2021), or otherwise find this to be more effortful and energydraining (Gierlinger, 2021; Talbot et al., 2021; cf. De Smet et al., 2018; Thompson \& Sylvén, 2015). As the success of educational reforms depend on its stakeholders (e.g., Cross \& Hong, 2012; Fullan \& Hargreaves, 2014; Gruber, 2017; Gruber et al., 2020), and as periods of innovation and change can be destabilizing (Day, 2007), understanding which factors impact the psychologies of teachers and learners, and how they adapt to such factors is centrally important in supporting them as they perform their roles in ICL contexts (Cross \& Hong, 2012).

\section{About the Papers in this Special Issue}

In this special issue, there are six regular papers, one work-in-progress paper from an on-going research project, and a book review. The papers feature various psychological domains and constructs, including agency, identity, metacognition, anxiety, affect, appraisal, attitudes, well-being, and beliefs. In the first paper, Kristiina Skinnari (University of Jyväskylä, Finland) presents a qualitative study of how CLIL teachers in different contexts (i.e., Austria, Finland, \& Spain) experience and enact their agency in the midst of CLIL-related challenges. Notably, she uses the Listening Guide method (Gilligan, 2015), a form of narrative analysis that allows for multiple readings of data, in conjunction with thematic analysis to analyze her data.

In the second paper, Yolanda Ruiz de Zarobe (University of the Basque Country, Spain) and Simone Smala (University of Queensland, Australia) present this special issue's lone theoretical contribution; the authors compare two previous CLIL studies, one related to strategy instruction, and the other related to language learning strategies, in order to propose a conceptual framework based on the notion of metacognitive awareness. The researchers posit that metacognitive awareness can be understood as a useful linking factor for teachers, students, and CLIL classrooms.

In the third regular paper, Julia Goetze (Pennsylvania State University, USA) investigates how tertiary-level German teachers in a CLIL-like setting verbally construe classroom anxiety. To analyze her data, Goetze combines aspects of systemic functional linguistics (Martin \& White, 2005) with appraisal theory (Smith \& Lazarus, 1993) to better understand how her sample of teachers verbalized their anxiety and beliefs in interviews.

Paper 4 by Nashwa Nashaat Sobhy (Universidad Politécnica de Valencia, Spain) and Davinia Sánchez Garcia (Universidad Complutense de Madrid, Spain) examined the attitudes of tertiary-level lecturers across Europe toward the use of English as a lingua franca (ELF). Their dataset draws on lecturers' written exchanges from an EMI training module. Notably, the authors, like Goetze, employ Martin and White's (2005) appraisal theory to uncover the valence of lecturer's attitudes in written responses towards ELF.

Paper 5 by Gianna Hessel (University of Graz, Austria) together with Kyle Talbot, (University of Graz, Austria), Marie-Theres Gruber (KPH Graz, Austria) and Sarah Mercer (University of Graz, Austria) outlines a quantitative 
study comparing secondary CLIL and tertiary EMI teachers' well-being, job satisfaction, job attitudes, and beliefs in Austria. The data in their study suggest that there may be more risk for teachers at one educational level than others.

The last regular paper, Paper 6, finds Josephine Moate and Maria Ruohotie-Lyhty (University of Jyväskylä, Finland) exploring how identity and agency interact in individual development. In their qualitative study, they look at reflective essays gathered from pre-service teachers partaking in a CLIL-based teacher education program in Jyväskylä. They take an ecological perspective to make sense of this interplay between identity and agency and how this develops in pre-service teacher development.

In addition to the regular papers, Silvia BauerMarschallinger (University of Vienna/KPH ViennaKrems, Austria) presents data from an on-going study which focuses on the development of research-based transdisciplinary CLIL teaching materials that are created in conjunction with input from the CLIL students themselves. Her study foregrounds students' voices which are gathered with the help of focus group interviews.

Finally, Dorota Záborská (Heian Jogakuin University, Japan) reviews the edited collection "Contemporary Language Motivation Theory,” a recent publication in the Psychology of Language Teaching and Learning series from Multilingual Matters. The book, a festschrift in tribute to Robert (Bob) C. Gardner, the "father of language motivation," was edited by Ali H. Al-Hoorie and Peter D. MacIntyre, and celebrates the various contributions that Bob Gardner has made in the domain of language motivation research.

\section{Acknowledgments}

The guest editors would like to gratefully acknowledge the ÖNB fund no. 17136, entitled "Selbstbild \& professionelles Wohlbefinden von CLIL Lehrenden" for their generous grant. Rieko Nishida's participation was made possible through the JSPS Grant-in-Aid for Scientific Research (B), KAKENHI Grant Number 17H02359.

Specifically, in need of thanks are the authors for their contributions - it was truly a pleasure to edit these papers. Essential to the development of the papers were the external reviewers who undoubtedly helped improve the quality of this special issue. Furthermore, we are extremely grateful to the founding JPLL Editors-in-Chief Jo Mynard, Imelda Brady, and Sarah Mercer for accepting our proposal for this special issue and for the early guidance. We are equally grateful to current Editors-in-Chief Phil Hiver, Shaofeng Li, and Ali AlHoorie for helping us cross the finish line. Special thanks also to Isobel Wang who was of great assistance at the beginning of the editing process.

\section{REFERENCES}

Aiello, J., Di Martino, E., \& Di Sabato, B. (2015). Preparing teachers in Italy for CLIL: Reflections on assessment, language proficiency and willingness to communicate. International Journal of Bilingual Education and Bilingualism, 20(1), 69-83.

https://doi.org/10.1080/13670050.2015.1041873

Banegas, D. L. (2012). CLIL teacher development: Challenges and experiences. Latin American Journal of Content and Language Integrated Learning, 5(1), 46-56. https://doi.org/10.5294/laclil.2012.5.1.4
Bovellan, E. (2014). Teachers' beliefs about learning and language as reflected in their views of teaching materials for content and language integrated learning (CLIL) [Doctoral dissertation, University of Jyväskylä]. University Library of Jyväskylä. https://jyx.jyu.fi/bitstream/handle/123456789/4427 7/978-951-39-5809-

1_vaitos20092014.pdf?sequence

Cenoz, J., Genesee, F., \& Gorter, D. (2014). Critical analysis of CLIL: Taking stock and looking forward. Applied Linguistics, 35(3), 243-262. https://doi.org/10.1093/applin/amt011

Coyle, D. (2013). Listening to learners: An investigation into ‘successful learning' across CLIL contexts. 
International Journal of Bilingual Education and Bilingualism, 16(3), 244-266.

https://doi.org/10.1080/13670050.2013.777384

Cross, D. I., \& Hong, J. Y. (2012). An ecological examination of teachers' emotions in the school context. Teaching and Teacher Education, 28, 957-967.

https://doi.org/10.1016/j.tate.2012.05.001

Day, C. (2007). School reform and transitions in teacher professionalism and identity. In T. Townsend, \& R. Bates (Eds.), Handbook of Teacher Education: Globalization, Standards and Professionalism in Times of Change (pp. 597-612). Springer. https://doi.org/10.1007/1-4020-4773-8_41

Dearden, J. (2015). English as a medium of instruction - A growing global phenomenon. British Council.

De Smet, A., Mettewie, L., Galand, B., Hiligsmann, P., \& Van Mensel, L. (2018). Classroom anxiety and enjoyment in CLIL and non-CLIL: Does the target language matter? Studies in Second Language Learning and Teaching, 8(1), 47-71. https://doi.org/10.14746/ssllt.2018.8.1.3

Doiz, A., \& Lasagabaster, D. (2018). Teachers' and students' second language motivational self system in English-medium instruction: A qualitative approach. TESOL Quarterly, 52(3), 657-679. https://doi.org/10.1002/tesq.452

Doiz, A., Lasagabaster, D., \& Sierra, J. M. (2014). CLIL and motivation: The effect of individual and contextual variables. The Language Learning Journal, 42(2), 209-224. https://doi.org/10.1080/09571736.2014.889508

Fullan, M., \& Hargreaves, A. (Eds.). (2014). Teacher development and educational change (1st ed.). Routledge. https://doi.org/10.4324/9781315870700

Gierlinger, E. M. (2007). Modular CLIL in lower secondary education: Some insights from a research project in Austria. In C. Dalton-Puffer, \& U. Smit (Eds.), Empirical perspectives on classroom discourse (pp. 79-118). Peter Lang. https://doi.org/10.3726/978-3-653-01829-5/5
Gierlinger, E. M. (2021). L2 confidence in CLIL teaching: A tale of two teachers. In K. R. Talbot, M.-T. Gruber, \& R. Nishida (Eds.), The psychological experience of integrating content and language. Multilingual Matters.

Gilligan, C. (2015). The Listening guide method of psychological inquiry. Qualitative Psychology, 2, 69-77. https://doi.org/10.1037/qup0000023

Griva, E., Chostelidou, D., \& Panteli, P. (2014). Insider views of CLIL in primary education: Challenges and experiences of EFL teachers. International Journal for Innovation Education and Research, 2, 31-53.

Gruber, M.-T. (2017). PrimA-CLIL: Multiple stakeholders' perceptions of CLIL and its implementation at the primary school level in Austria. [Doctoral dissertation, University of Graz].

Gruber, M.-T., Lämmerer, A., Hofstadler, N., \& Mercer, S. (2020). Flourishing or floundering: Factors contributing to CLIL primary teachers' wellbeing in Austria. CLIL Journal of Innovation and Research in Plurilingual and Pluricultural Education, 3(1), 19-34. https://doi.org/10.5565/rev/clil.24

Hüttner, J., Dalton-Puffer, C., \& Smit, U. (2013) The power of beliefs: Lay theories and their influence on the implementation of CLIL programmed. International Journal of Bilingual Education and Bilingualism, 16(3), 267-284. https://doi.org/10.1080/13670050.2013.777385

Klaassen, R. G., \& De Graaff, E. (2001). Facing innovation: Preparing lecturers for Englishmedium instruction in a non-native context. European Journal of Engineering Education, 26(3), 281-289. https://doi.org/10.1080/03043790110054409

Macaro, E., Curle, S., Pun, J., An, J., \& Dearden, J. (2018). A systematic review of English medium instruction in higher education. Language Teaching, 51(1), 36-76. https://doi.org/10.1017/s0261444817000350 
Martin, J. R., \& White, P. R. R. (2005). The language of evaluation: Appraisal in English. Palgrave Macmillan. https://doi.org/10.1057/9780230511910

Moate, J. (2011). Voicing the challenges faced by an innovative teacher community. Teachers and Teaching, 17(2), 255-268.

https://doi.org/10.1080/13540602.2011.539804

Pappa, S. (2021). Identity and emotions in teaching CLIL: The case of primary school teachers in Finland. In K. R. Talbot, M.-T. Gruber, \& R. Nishida (Eds.), The psychological experience of integrating content and language. Multilingual Matters.

Pappa, S., Moate, J., Ruohotie-Lyhty, M., \& Eteläpelto, A. (2017). Teachers' pedagogical and relational identity negotiation in the Finnish CLIL context. Teaching and Teacher Education, 65, 61-70. https://doi.org/10.1016/j.tate.2017.03.008
Noguera, P. A. (2006). A critical response to Michael Fullan's "The future of educational change: System thinkers in action.” Journal of Educational Change, 7(3), 129-132. https://doi.org/10.1007/s10833-006-0007-2

Smith, C. A., \& Lazarus, R. S. (1993). Appraisal components, core relational themes, and the emotions. Cognition \& Emotion, 7(3-4), 233-269. https://doi.org/10.1080/02699939308409189

Talbot, K. R., Gruber, M.-T., \& Nishida, R. (Eds.). (2021). The psychological experience of integrating content and language. Multilingual Matters.

Thompson, A. S., \& Sylvén, L. K. (2015). “Does English make you nervous?" Anxiety profiles of CLIL and non-CLIL students in Sweden. Apples - Journal of Applied Language Studies, 9(2), 1-23. https://doi.org/10.17011/apples/urn.201512093950 